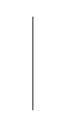

\section{Ksiażki o filmie} \\ „Kwartalnik Filmowy” nr 111 (2020) \\ ISSN: 0452-9502 (Print) ISSN: 2719-2725 (Online) \\ https://doi.org/10.36744/kf.413 \\ (c) Creative Commons BY-NC-ND 4.0 \\ Teresa Rutkowska \\ Instytut Sztuki Polskiej Akademii Nauk \\ https://orcid.org/o000-0002-2888-9206
}

\title{
Ukryty powab kina z czasów shusznie minionych
}

\author{
Słowa kluczowe: \\ kino polskie; \\ lata 70 .
}

\begin{abstract}
Abstrakt
Recenzja książki Justyny Jaworskiej pt. „Piękne widoki, panowie, stad macie". O kinie polskiego sockonsumpcjonizmu (2019), która otrzymała przyznawaną przez miesięcznik „Kino”, prestiżową nagrodę im. Bolesława Michałka za lata 2018-2019. Jaworska analizuje filmy zrealizowane na początku lat 70., w epoce Edwarda Gierka, która uchodziła za czas względnego dobrobytu, co obudziło w społeczeństwie polskim dążenie do poprawy sytuacji materialnej. Autorka szuka odzwierciedlenia tych tendencji w filmach uchodzących wówczas za nieudane (,słabe” w rozumieniu Vattimo) i sytuujących się poza kanonem dzieł, które zaznaczyły się w społecznej świadomości. Jej analizy dokonywane przez pryzmat obecnych diagnoz kulturowych - jak wskazuje recenzentka - są znakomicie napisane, błyskotliwe i przenikliwe, choć czasami kontrowersyjne. Kluczowym motywem tych filmów jest porażka egzystencjalna będąca udziałem większości bohaterów.
\end{abstract}




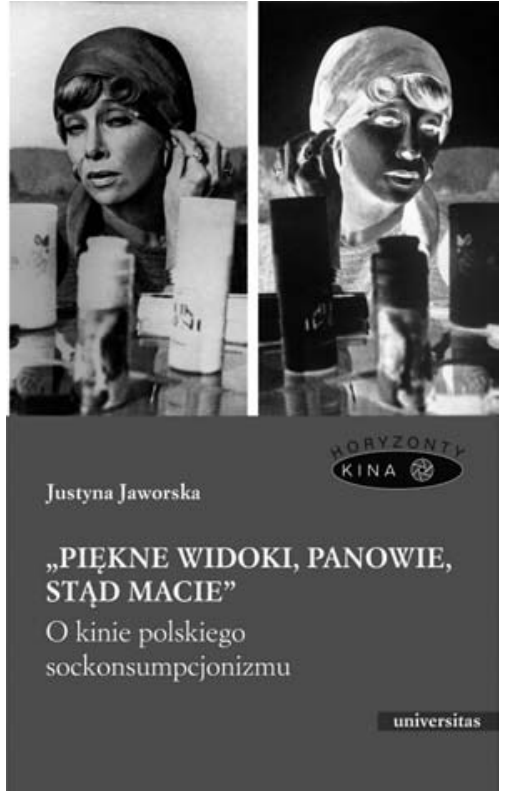

Historia kina, a zwłaszcza historia kina naszego, nie jest tylko kronika wydarzeń, rejestrem sukcesów i niepowodzeń, spisem nazwisk i tytułów. Spojrzenie wstecz, jak wszelkie myślenie historyczne, ujawnia coś więcej: skalę wartości społecznych i estetycznych naszego kina; rozgranicza wartości doraźne od trwatych, określa ogólny kierunek dą̇eń i sens osiagnięć; określa też miejsce kina w narodowej kulturze (...) - pisał Bolesław Michałek pod koniec lat 70., ${ }^{1}$ snując refleksje o polskim kanonie sztuki filmowej, który miałby obejmować filmy najmocniej obecne w ówczesnej świadomości społecznej, w przeświadczeniu, że utwory niezauważone, miałkie czy niedoskonałe słusznie są skazane na zapomnienie. Nie bez powodu przywołuję tu ideę tego krytyka. Justyna Jaworska jest bowiem laureatką nagrody im. Bolesława Michałka przyznanej w sezonie 2018-2019 za książkę "Piękne widoki, panowie,

stąd macie". O kinie polskiego sockonsumpcjonizmu. Tematem jej analizy jest kino początków lat 70., czyli u zarania epoki Gierkowskiej, z czasów, gdy na krótko (bo do starć robotniczych z milicją w czerwcu 1976 r. w Ursusie, Radomiu i Płocku z osławionymi ścieżkami zdrowia oraz do wprowadzenia bonów na cukier w sierpniu 1976 r.) społeczeństwo zyskało wiarę w możliwość poprawy statusu materialnego $\mathrm{w}$ ramach ustroju socjalistycznego i wynikające stąd jakże złudne poczucie większej sprawczości.

Paradoksalnie, bo niejako na przekór pojmowaniu historii kina przez Michałka, Jaworska skoncentrowała uwage przede wszystkim na filmach „codziennych”, jak by to powiedział Rafał Marszałek². Patronem jej rozważań mógłby być może też Krzysztof Mętrak, który dopominał się o docenienie filmów zapomnianych $^{3}$, jakkolwiek wiele miał do zarzucenia produkcjom z tamtych lat. Ona sama odwołuje się raczej do pojęcia „obrazów słabych”, bo gorzej wówczas ocenianych przez krytykę, pozostających - z pewnymi wyjątkami - na marginesie historii kina i zdecydowanie poza postulowanym przez Michałka kanonem. A jednak z różnych powodów wydają się jej one ciekawsze, między innymi z uwagi - jak wyjaśnia na skłonność do eksperymentowania $\mathrm{z}$ formą i oscylacji w kierunku kina gatunku, z większą dynamiką niż kiełkujące wówczas kino moralnego niepokoju. Postrzega je również jako szansę na wydobycie pewnych trudno uchwytnych, a ważnych manifestacji kulturowych. Owa słabość nie ma związku jedynie z wartością artystyczną tych filmów lub ich jakością techniczną (zwłaszcza w przypadku filmów kolorowych). Zresztą filmy takie, jak Trzeba zabić tę miłość (reż. Janusz Morgenstern) czy Dziewczyny do wzięcia (reż. Janusz Kondratiuk), zdecydowanie nie zasługiwałyby na taką dyskwalifikującą ocenę. Trudno przy tym ukryć, że przewrotnym kryterium doboru egzemplifikacji okazała się między innymi nagroda Skisłego Grona przyznawana dla najgorszego filmu roku na festiwalu Lubuskiego Lata Filmowego jako przeciwwaga dla lauru Złotego Grona. Nawet ta 
okoliczność skłania jednak Jaworską do obronnej dla tych filmów taktyki, wprawdzie czasem à rebours.

„Słabość" w tym ujęciu ma wielopoziomowy, złożony charakter. Badaczka powołuje się na Vattimo i jego koncepcję obrazów słabych $w$ sensie retorycznym (jako klisze, gry z konwencja, powidoki) (s. 76), zamierzona, autoironiczną albo mimowolną. Pisze więc: Tak czy owak porażka, czy to przewrotnie demaskowana, problematyzowana, czy najzwyczajniej odniesiona, wydaje się jedna z kluczowych kategorii dla ówczesnych filmów obyczajowych (s. 76).

Aby wyjść naprzeciw postawie badawczej autorki, trzeba jasno określić kontekst jej rozważań, zdecydowanie odmienny - co oczywiste - od tego, w jakim funkcjonowali filmoznawcy wcześniejszych pokoleń i widzowie, a także krytycy, oglądający te filmy „na bieżąco”. Istotne jest to, że obecnie dostrzega się w tych filmach co innego niż ongiś i sama ta różnica jest godna uwagi, płodna poznawczo, a zarazem nieuchronna, by nie powiedzieć strategiczna, niemal na miarę Derridiańskiej diffèrance. Sama Jaworska z tej różnicy (różni) czyni koło zamachowe swoich przemyśleń. W całym bowiem wywodzie odnosi się do recenzji z epoki, okazjonalnie też do protokołów kolaudacyjnych i relacjonowanych debat w dyskusyjnych klubach filmowych, czasem afirmatywnie, na potwierdzenie własnych osądów (dotyczy to zwłaszcza tekstów Rafała Marszałka i Krzysztofa Mętraka), częściej polemicznie lub wręcz prześmiewczo, co bywa zrozumiałe, zważywszy na ideologiczno-perswazyjny język, jakim bywały one formułowane, zwłaszcza w prasie najbardziej reżimowej, i zwietrzałą już czasem, a dziś nie do końca czytelną konwencję pisania nie wprost. Dawni widzowie (i krytycy) konfrontowali współczesne (ówcześnie) kino obyczajowe z własnymi doświadczeniami i obserwacjami, z własną biografią wewnętrzną, której PRL był nieredukowalną częścia, przykładając do tych filmów kryterium wiarygodności, z wyczuleniem na podteksty, kody porozumienia wyznaczane przez język ezopowy, a także ewidentne zafałszowania. Utwory takie miały w owym czasie byt o wiele bardziej ulotny, przewijały się przez ekrany i znikały. Podział na kino popularne i wysokoartystyczne wyznaczał granice kompetencji kulturowych. W pewnym sensiei temu zagadnieniu w znacznej mierze poświęcili swoje życie zawodowe krytycy tacy na przykład, jak Tadeusz Sobolewski czy Tadeusz Lubelski, nasze najlepsze kino, zrodzone na gruncie klęsk i nieszczęść zbiorowych, miało moc terapeutyczna, uruchamiało wyobraźnię i siłę mitotwórcza, leczyło z poczucia przegranej, klęskę obracało w poczucie zwycięstwa $a^{4}$ w przeświadczeniu że prawdziwa sztuka nie daje się ujarzmić sile politycznej. Kanon, o którym była mowa wcześniej, nie był więc artystowską fanaberią, ale strategią obronną wobec zniewolenia, bez względu na to, jak obecnie oceniać jej skuteczność. Dziś - i jest to naturalny proces transformacji kulturowo-pokoleniowej - historycy filmu poddają te filmy surowej ocenie i weryfikują dawne znaczenia, schematy intelektualne i hierarchie artystyczne, czego przykładem są choćby publikacje z kręgu Krytyki Politycznej i co jest okrutnym w pewnym sensie dowodem na żywotność tej dziedziny badawczej.

Justyna Jaworska także brawurowo i radykalnie odcina się od podłoża, szuka nieoczywistych koneksji, na przykład z obszaru kina zachodniego (zdarza się, że filmy, na które się powołuje, były wtedy znane nielicznym szczęściarzom), filtruje swoje spostrzeżenia przez pryzmat światowej literatury przedmiotu, zderza 
diagnozy przesytu konsumpcyjnego w społeczeństwie kapitalistycznym rodem z Jeana Baudrillarda czy Deana McCannela i nie tylko z przaśna, szara, polską rzeczywistością, której współuczestnicy, tęskniąc za zdobyczami cywilizacyjnymi, próbowali zaspokoić swoje aspiracje niedoskonałym ersatzem. Czerpie też wsparcie intelektualne z przenikliwych opracowań historycznych dotyczących epoki PRL-u, autorstwa takich między innymi badaczy, jak Michał Głowiński, Małgorzata Szpakowska czy Joanna Krakowska. Przyglądając się uważnie filmom obyczajowym z epoki wczesnego Gierka, przykłada do nich nowy, własny szablon analityczny, wykorzystuje przy tym nowoczesne narzędzia metodologiczne. Pojęciem, które strukturuje jej wywód, jest sockonsumpcjonizm, termin-oksymoron, za którym kryło się pragnienie posiadania zarówno rzeczy koniecznych do życia w czasach wiecznych niedoborów wszystkiego, jak i tych nieosiągalnych dla zwykłych zjadaczy chleba. Z właściwą sobie ironią zreasumował kiedyś ten niedosyt Rafał Marszałek, krytyk z ostrym zacięciem socjologicznym, w książce Kino rzeczy znalezionych ${ }^{5}$ poświęconej wyznacznikom filmowym codziennej rodzimej egzystencji, eksplorując motywy takie, jak: Od dachu nad głowa do antycznej sauny, czy Kobieta z papierem toaletowym i innymi łupami sklepowymi pozwalajacymi żyć godnie i szczęśliwie (wyodrębnione w tytułach rozdziałów).

Wspomniane pojęcie sockonsumpcjonizmu Jaworska wyłuskała z książki Tadeusza Nyczka poświęconej kabaretowi Salon Niezależnych ${ }^{6}$, w której autor sarkastycznie stwierdza, że ów sockonsumpcjonizm tym zaś się różni od zwykłego konsumpcjonizmu, z którym mamy do czynienia obecnie, że stawia pewien warunek: jak się ma pełen pysk, należy ten pysk trzymać zamknięty. Przedrostek soc- jest więc u Jaworskiej wskazaniem na zasadniczą ułomność systemową, która sprawiała, że w opisywanych filmach (a przede wszystkim w samej rzeczywistości tamtych lat) konsumpcja była naznaczona upokarzającym brakiem i niemożnością. Aspiracje społeczne często więc pozostawały niezaspokojone, ale także odznaczały się przygnębiającą wtórnością wobec dynamiki i ekspansywności popularnych trendów europejskich (czy światowych). To przeświadczenie znajduje poniekąd wyraz w samej stylistyce wywodu zawartego w omawianej książce. Opis zjawisk często zyskuje tu taką właśnie kwalifikację naśladowcza, jak „,kłir” jako rodzima wersja queeru, gdzie heteronorma, wzorce męskości i kobiecości, przeobrażają się w swoją własną karykaturę (jak w Dziewczynach do wzięcia, ale też w innych filmach Janusza Kondratiuka). Nawiązując do tych szczególnych polskich kompleksów, Jaworska celowo posługuje się kliszami stylistycznymi (czerpanymi obficie z dawnych recenzji) nakazującymi w Anatomii miłości widzieć "polską Love story”, z Barbarą Brylską jako "polską Anouk Aimée” i Janem Nowickim jako "polskim Jean-Louisem Trintignantem", czy określać aktorki, takie jak Barbara Wrzesińska (Trzeba zabić tę miłość) czy Katarzyna Kaczmarek (aktorka jednej roli, Krysi, w Rewizji osobistej) jako „polskie Brigitte Bardot”, co pozwala jej równocześnie zarysować nasz krajowy ubogi filmowy „alfabet scen miłosnych”.

Korpus książki tworzą analizy wspomnianych filmów, znakomicie i z werwą napisane, innowacyjne i niebanalne. Nie znaczy to, że interpretacje te nie budzą kontrowersji i nie prowokują do polemiki. Warto podkreślić, że autorka świadomie ucieka się do konwencji przerysowań i ironii, choć jej rozpoznania są merytorycznie ciekawe i zaskakujące. Jak podkreśla, inspiracją dla niej była koncepcja wywrotowej sztuki porażki Judith Halberstam (s. 46). 
Filmy, którym poświęca szczególną uwagę, to Dzięcioł Jerzego Gruzy (1970), Dziewczyny do wzięcia (1972), Anatomia miłości Romana Załuskiego (1972), Trzeba zabić tę miłość (1972), Rewizja osobista Andrzeja Kostenki i Witolda Leszczyńskiego (1972) i Motylem jestem, czyli romans czterdziestolatka Jerzego Gruzy (1976), rozpatruje też okazjonalnie na wsparcie swoich tez inne przykłady, niekiedy cofając się o kilka lat lub wybiegając do przodu, także dlatego, że sam filmowy proces produkcyjny i dystrybucyjny wymyka się ścisłej kategoryzacji czasowej. Jednak rok 1972 wyznaczający premiery wymienionych utworów jest tu istotny. Autorka sytuuje "małą odwilż" w branży filmowej między styczniem 1972 r. a grudniem 1973 r., wskazując że w tym okresie zespoły filmowe zyskały nieco większą dozę samodzielności (zanim przywrócono ściślejszą kontrolę partyjną), a obietnice Gierka w dziedzinie gospodarczej i politycznej zaczęły przyoblekać się w rzeczywistość.

Filmem wielokrotnie przywoływanym i najbardziej symptomatycznym jest tu Rewizja osobista (nagroda Skisłego Grona w 1976 r.), którą już przed laty Edwin Bendyk opisał przewrotnie jako doskonały wyraz krytyki społeczeństwa konsumpcyjnego z perspektywy mieszkańca kraju realnego socjalizmu ${ }^{7}$. Na forach internetowych film ten ma zagorzałych zwolenników, którzy odnajdują w nim wręcz kampowy potencjał. W swoim czasie był dość konsekwentnie gromiony przez krytyków i został zignorowany przez widzów, Jaworska jednak dowodzi, że film jest ciekawszy, niż ongiś sądzono. Śledzi tu wątek socjopsychologiczny, związany z kapitulacją świadomości socjalistycznej wobec magicznej mocy zachodnich dóbr konsumpcyjnych i dwuznacznością przekazu wynikającą z rozdarcia między fascynacją a potępieniem.

Nawet więc, jeśli nie do końca zgadzam się z przewartościowaniami, jakich dokonuje ona w swoich ocenach (złe filmy jednak pozostają w moim odczuciu złymi filmami), należy docenić jej nieschematyczny i kreatywny styl myślenia o polskim kinie tamtych lat, ale także - co wcale nie jest częste - talent literacki. Koncept porażki egzystencjalnej jako motywu przewodniego omawianych filmów jest bardzo interesujący, natomiast ranga materialnego konsumpcjonizmu (nawet z przedrostkiem soc-) jako regulatora zachowań i relacji społecznych we wczesnych latach 70. wydaje mi się nieco przesadzona, zwłaszcza gdy podlega - jak tu - generalizacji.

Justyna Jaworska, "Piękne widoki, panowie, stąd macie”. O kinie polskiego sockonsjumpcjonizmu, Universitas, Kraków 2019.

${ }^{1}$ B. Michałek, Ambasador polskiego kina. Wspomnienia i artykuły, Rabid, Kraków 2002, s. 219.

${ }^{2}$ R. Marszałek, Pamflet na kino codzienne, Wydawnictwo Literackie, Kraków 1974.

${ }^{3}$ K. Mętrak, Ocalić od zapomnienia, "Kino" 1974, nr 9, s. 18-19.

${ }^{4}$ T. Sobolewski, Dziecko Peerelu. Esej, dziennik, Wydawnictwo Sic!, Warszawa 2000, s. 25.

${ }^{5}$ Por. tytuły rozdziałów w: R. Marszałek, Kino rzeczy znalezionych, słowo/obraz terytoria, Gdańsk 2006.

${ }^{6}$ T. Nyczek, Salon Niezależnych. Dzieje peznnego kabaretu, Wydawnictwo Znak, Kraków 2008, s. 69 .
${ }^{7}$ Por. E. Bendyk, "Rewizja osobista” Andrzeja Kostenki i Witolda Leszczyńskiego, w: Polish New Wave. The History of the Phenomenon That Never Existed / Polska Nowa Fala. Historia Zjawiska, którego nie było, red. Łukasz Ronduda i Barbara Piwowarska, Centrum Sztuki Współczesnej i Instytut Mickiewicza, Warszawa 2008, s. 190 i tegoż, Miłość, wojna, rewolucja. Szkice na czas kryzysu, Wydawnictwo WAB, Warszawa 2009. 
Teresa Rutkowska
Emerytowana redaktor naczelna „Kwartalnika Filmowego”. Publikuje w „Nowych Książkach”; thumaczka. Interesuje się problemami narracji i relacji między obrazem a słowem w filmie

\section{Bibilografia}

Bendyk, E. (2009). Miłość, wojna, rewolucja. Szkice na czas kryzysu. Warszawa: Wydawnictwo W.A.B.

Jaworska, J. (2019). „Piękne widoki, panowie, stad macie”. O kinie polskiego sockonsumpcjonizmu. Kraków: Towarzystwo Autorów i Wydawców Prac Naukowych „Universitas".

Marszałek, R. (1974). Pamflet na kino codzienne. Kraków: Wydawnictwo Literackie.

Marszałek, R. (2006). Kino rzeczy znalezionych. Gdańsk: słowo/obraz terytoria.

Mętrak, K. (1974). Ocalić od zapomnienia. Kino, 9.

Michałek, B. (2002). Ambasador polskiego kina. Wspomnienia i artykuly. Kraków: Wydawnictwo Rabid.

Nyczek, T. (2008). Salon Niezależnych. Dzieje peжnego kabaretu. Kraków: Społeczny Instytut Wydawniczy „Znak”.

Ronduda, L., Piwowarska, B. (red.) (2008). Polish New Wave. The History of the Phenomenon That Never Existed / Polska Nowa Fala. Historia Zjaziska, którego nie było. Warszawa: Centrum Sztuki Współczesnej i Instytut Mickiewicza.

Sobolewski, T. (2000). Dziecko Peerelu. Esej, dziennik. Warszawa: Wydawnictwo Sic!

\footnotetext{
Keywords:

Polish cinema; seventies, socialist realism, soc-consumptionism Abstract
Teresa Rutkowska
The Hidden Lure of Cinema From the Times Rightly By-
gone
A review of Justyna Jaworska's book "Piekne widoki, panowie,
stad macie". Okinie polskiego sockonsumpcjonizmu ["Beautiful
Views, Gentlemen, You Have From Here": About the Cinema of
Polish Soc-consumptionism] (2019), which was awarded the
Bolesław Michałek Award by the monthly Kino for the pe-
riod 2018-2019. Jaworska analyzes films made in the early
197os, in the era of Edward Gierek, which was regarded as
a time of relative prosperity that awakened in Polish society
the aspirations to improve the material situation. Jaworska
looks for a reflection of these trends in films that were con-
sidered unsuccessful (and "weak" in Vattimo's meaning of
the word) at the time and found themselves outside the
canon of works that were marked in the social conscio-
usness. Her analyses made through the prism of current
} 
cultural diagnoses - as the reviewer points out - are brilliant, excellently written and penetrating, although sometimes controversial. The key theme of these films is the existential failure that most of the protagonists have experienced. 